\title{
Palánkai Tibor nyolcvanéves
}

A hazai integrációs kutatások értékelése lehetetlen vállalkozás volna Palánkai Tibor munkásságának ismerete nélkül. E közel hat évtizedes, még ma is rendkívül színes és aktív pálya meghatározó módon alakította és alakítja mindannyiunk gondolkodását a nemzetközi és európai integrációs folyamatokról és elméletekről. Palánkai Tibornak köszönhetően nyerhettünk betekintést a nemzetközi integrációelméletekbe, a vámunió-elméletekbe, az optimális valutaövezetek elméletébe vagy éppen az integráció mérésének technikáiba.

Úgy vált nemzetközileg is elismert szaktekintéllyé, hogy közben mindvégig hüséges maradt szükebb szakmai közösségéhez, a Közgázhoz. A Marx Károly Közgazdaságtudományi Egyetem hallgatójaként végzett 1960-ban. 1982-ben már az egyetemi tanári cím birtokosa. Erre az időszakra (1977-1983) esett tudományos rektorhelyettesi ténykedése is. Magyarország ekkorra már túl volt az új gazdasági mechanizmuson, és egyértelmüen a visszarendeződés jelei mutatkoztak, ám az oktatás reformja nem állt le. Nem is állhatott, hiszen egyértelmüvé vált, hogy Magyarország nagyon is része a világgazdaságnak, nem tartóztathatja fel határainál mindazon kihívásokat, amelyekkel a hetvenes évek olajválságainak köszönhetően a megosztott világrend mindkét tábora kénytelen volt szembesülni. E kényszerek formálták mind a világgazdaságtan, mind pedig a politikai gazdaságtan diszciplínáit, amelyek alakításában, újraformálásában Palánkai Tibor maga is tevékenyen részt vett.

A rendszerváltást követően, 1997 és 2000 között - immár Budapesti Közgazdaságtudományi Egyetem név alatt - az intézmény rektora volt. Rektorsága idején a Magyar Akkreditációs Bizottság tagjaként is szerepet vállalt az oktatás minőségbiztosításában (a közgazdasági szakbizottság elnökeként). De a rektorhelyettesi és rektori pozíciók közötti időszakban sem „tétlenkedett”: 1983 és 1995 között az egyetem egyik legkorábban alapított szakmai mühelyét, a Világgazdasági Tanszéket vezette, ahol pályáját is kezdte, és amelynek jelenleg is aktív oktatója-kutatója, immár emeritusként. Alapítása óta törzstagja a Budapesti Corvinus Egyetem Nemzetközi Kapcsolatok Multidiszciplináris Doktori Iskolának (19 védett hallgatóval), amelynek korábban elnöke is volt. Kutatói tevékenységét előbb az MTA levelező (1995), majd rendes (2004) tagságával ismerték el. 
Kutatott Ford-ösztöndíjjal az Egyesült Államokban (1966-1967), vendégkutató volt a Sussexi Egyetemen (1971), majd a Padovai Egyetemen (1987) és a Helsinki Közgazdaság- és Gazdaságtudományi Iskolán (1992-1993). A rendszerváltás idején (19891990) a New York-i székhelyü Kelet-Nyugat Biztonsági Kutatóintézet vendégkutatója volt. Egy évtizeden át (1994-2004) saját kurzussal (Közép-Kelet-Európa integrációja) volt jelen a bruges-i College of Europe-ban.

1970-től az MTA Modern Kapitalizmus Kutatás Magyar Nemzeti Bizottsága mellett működő integrációs munkacsoport vezetésével bízták meg, a rendszerváltás előtti tíz esztendőben (1980-1990) pedig a nemzetközi integrációs munkacsoport elnökeként tevékenykedett. Az európai integrációs stúdiumok megfellebbezhetetlen szaktekintélyeként tevékenyen részt vállalt Magyarország uniós tagságának elökészítésében. Az integrációs stratégiai munkacsoport gazdaságpolitikáért felelős szekcióját vezette (1996-1998), majd az EU-csatlakozást támogató Kommunikációs Közalapítvány elnöke lett (2002-2004). 1994-ben az elsők között nyerte el a Jean Monnet-professzori címet az Európa-tanulmányok terén végzett kimagasló oktatói és kutatói tevékenységéért. 2001-ben az Európai Bizottság mellett müködő Európai Egyetemi Tanács (Conseil Universitaire Européen) tagjává választották, ahol a csatlakozó országokat képviselte. 2007-ben a Jean Monnet ad Personam cím tulajdonosa lett.

Tudományos munkásságáért elnyerte az Akadémiai Díjat (1994). 1998-ban a Magyar Köztársaság Érdemkeresztjét, valamint a Deák Ferenc-díjat. 2008-ban az Magyar Közgazdasági Társaság által adományozott Kautz Gyula-díj birtokosa lett. 2009-ben Széchenyi-díjjal tüntették ki. 2010-ben Jean Monnet-díjban részesült.

Pályája indulásától az európai integráció kérdései foglalkoztatták. 1973-ban írott kandidátusi értekezésének címe A nemzetközi gazdasági integráció néhány elméleti kérdése volt. Akadémiai doktori értekezését (1986) az iparilag fejlett országok világgazdasági alkalmazkodásának témakörében jegyezte. Mindmáig e területek tekinthetők Palánkai Tibor meghatározó kutatási irányainak - kiegészítve természetesen Magyarország (és a régió) EU-tagságra való felkészülésével, majd az EU-tagsággal járó kihívások elemzésével. A gazdasági és monetáris unió, a gazdaságpolitikai koordináció, az euró bevezetése, az integráció mérése, valamint az EU külső kapcsolati modelljeinek kérdései mind fellelhetők (aktuális) kutatási (és oktatási) témái között. Rendkívül termékeny szerző, 500 feletti tudományos és felsőoktatási közleménnyel.

Legismertebb munkája Az európai integráció gazdaságtana címü összefoglaló kötet, amely meghatározó módon alakította generációk gondolkodását az integrációs folyamatokról, valamint az EK/EU intézményrendszeréről. A könyv minden meghatározó felsőoktatási intézmény tanrendjében - bevezető és haladó kurzusokon - kötelező olvasmány volt, vagy még ma is az. Azok, akik az EU intézményrendszerében dolgoznak (itthon vagy külföldön), valamint az integrációt érintő kérdésekkel foglalkoznak, szinte bizonyosan ismerik. Csakhogy ez a monográfia merőben más, mint a nyugati katedrákon használt legtöbb ilyen jellegü kötet. Palánkai Tibor ugyanis még csak véletlenül sem amellett érvel(t), hogy szükség volna valamifajta önálló (egyetlen) elméletre az európai integráció magyarázatában. Ahogy nem kötelezte el magát egyik vagy másik nagy integrációelmélet mellett sem. Következetesen regionális együttmüködés(ek)röl, valamint regionális 
gazdasági integrációról, sőt integrációkról beszél(t). Habár a kötet címe vállaltan európai központú, mégis kinyilvánítja: az integrációs folyamat nem értelmezhető a világgazdaság más folyamataitól elválasztva.

A kötet és Palánkai vizsgálódásának általában is nagy erénye, hogy a világgazdaságot olyan organikus egységként fogja fel, amely több mint a részek összessége. A nemzetközi gazdaságtan kategóriái és módszerei következésképpen nem elégségesek a globalizáció támasztotta kihívások és lehetőségek számbavételére, elemzésére és értékelésére. A vizsgálódás ugyanis nem korlátozódhat a szűken vett államközi kapcsolatokra. Egyfelől maguk az államok sem feketedobozként müködnek, másfelől a világméretü gazdasági folyamatokat exponenciális számban bővülő nem állami, transz- és szupranacionális szereplők (is) alakítják. Már a hetvenes években is érezhető volt, de a nyolcvanas évek végétől a világ ezen szegletében is egyértelmüvé vál(hatot)t az interdependenciák erősödése, a piacok globalizálódása, a multiés transznacionális vállalati együttmüködések kiterjedése stb.

Palánkai munkáira általában is jellemző, hogy ebben a szélesebb értelemben vett kontextusban értelmezi a regionális együttmüködéseket, a regionális szintủ gazdasági integrációkat. Igyekezete legfőképpen arra irányul, hogy bizonyítsa: a regionális integráció egyfelől csak a globalizáció folyamataival együtt értelmezhető, másfelől - bár jellegéből adódóan szűkebb földrajzi régióra terjed ki - semmiképpen sem ellentéte a globalizációnak. A két folyamat - a globalizáció és a regionális integráció - ugyanis szoros szimbiózisban fejlődik, egyik a másik nélkül nem értelmezhető. Palánkai célja tehát mindezen folyamatok „természetének, törvényszerüségeinek, hatásmechanizmusainak, gazdasági és társadalmi következményeinek... az elemzése" (Palánkai [1995/1999] 11. o.).

Ez a meggyőződés még erőteljesebben nyilvánul(t) meg következő nagy munkájában, A globális és regionális integráció gazdaságtanában. Itt - elhagyva az európai jelzőt - már a címben is kifejeződik, hogy úgy kívánja meghaladni a nemzetközi gazdaságtan államközpontú magyarázatait, hogy egységes keretben reflektál a globalizáció és a regionalizmus jelentette kihívásokra. A kötet egy új, a magyar szakirodalomban addig nem ismert diszciplínát kíván meghonosítani, az összehasonlító regionális integrációs tanulmányokat. A globalizációt olyan „nagy átalakulásnak" tekinti, amelynek tartalma maga a globális integráció (Palánkai és szerzötársai [2011] 29. o.). ${ }^{1}$ Az integrációt következésképpen a globalizáció egyik alapvető dimenziójaként fogja fel. Kinyilvánítja: „[a] globális és regionális integráció összefüggése és szoros kölcsönhatása jellemző. A globális integráció regionálisan sürüsödik, regionális integrációs szervezetekkel strukturálódik. Ezek egymást erősítik, egymásra rétegződnek..." (Palánkai és szerzőtársai [2011] 9. o.)

A „nagy átalakulás” témaköréhez később sem lett hütlen. Egyik legfrissebb tanulmányában, melyben Piketty nagy hatású könyve alapján fogalmazza meg reflexióit, úgy érvel, hogy a társadalomtudományi vizsgálódásnak „ki kell terjednie a

\footnotetext{
${ }^{1}$ Maga a kötet ugyan többszerzős (Palánkai Tibor mellett Kengyel Ákos, Kutasi Gábor, Nagy Sándor Gyula és Benczes István voltak a szerzőtársak), de nemcsak a legtöbb fejezetet jegyzi, hanem a kötet egészének szemlélete is egyértelműen az ő meggyőződését, világlátását fejezi ki.
} 
technostruktúrákra, a társadalmi és gazdasági szerkezetek alakulására, a társadalmi viszonyok és az intézmények fejlődésére, azok egymással szemben kialakuló viszonylataira, a hatalmi struktúráikra, valamint az emberre hiedelmeivel, tudásával, kultúrájával, magatartási és erkölcsi normáival együtt” (Palánkai [2017a] 34. o.).

E korszakváltás az oktatásban (így a felsőoktatásban) érdekelteket is arra kell sarkallja, hogy „beleálljanak” e változásokba. A kataklizmák csapdája címmel megjelent szerkesztett kötethez készített interjúban megfogalmazza, hogy hibás felfogás az, miszerint az oktatásnak pusztán a szüken vett munkaerőpiaci igényeket kellene kielégítenie. Ehelyett arra kell törekednünk, hogy minél szélesebb műveltséggel vértezzük fel az iskolapadból kikerülőket, akiknek tudása jól konvertálható az egyes területek között. Az oktatási rendszernek a globális változások közepette biztosítania kell azt a differenciált szemléletet, amelyben mindenki képessé válhat kibontakoztatni a benne rejlő tehetséget (Tóth [2006]).

Palánkai Tibor munkásságának, nemzetközi léptékben is elismert területe az integráció (illetve integráltság) mérése. A mérés ez esetben nem egyszerüen mennyiségi számbavételt jelent. Az egyértelmüen kvantitatív jellemzőkön túl ugyanis Palánkai igyekszik az integráció olyan dimenzióit is számba venni, mint az integrációs folyamatok struktúrája, szerkezeti jellemzői, kiegyensúlyozottsága stb. Saját fejlesztésü módszertan alapján tett kísérletet Magyarország integrációs helyzetének (illetve reálgazdasága integrációérettségének) mérésére az integrációs profil módszerével. Az elemzésbe egyebek mellett a kereskedelmi, valamint tőkekapcsolatok intenzitását, a magyar gazdaság szerkezetét és annak átalakulását, a teljesítményi és függőségi viszonyokat, illetve a reálgazdasági konvergenciát vonta be (Palánkai-Miklós [2014]).

Az újra erőre kapó hazai euróvitában is egyértelmü és határozott álláspontot képvisel. Az eurót azon az alapon tartja nem politikai terméknek, hogy bevezetése mellett „kemény reálgazdasági” érvek, a „tagországok gazdaságának (...) igen magas integráltsági szintje" áll. I Írásaiban a GMU-projekt indulása óta meggyőződéssel érvel amellett, hogy az egységes piac, amelynek vívmányait a közös pénz ellenzői sem vonják kétségbe, nem teljesedhet ki a közös valuta nélkül, az egységes valuta ugyanis a globális versenyképesség alapvető tényezője (Palánkai [2015]). Nemcsak Magyarország EU-tagságának kérlelhetetlen támogatója, hanem az ország euróövezethez való csatlakozásának is meggyőződéses pártolója. Meggyőződéssel vallja: „az euróövezeti belépés és tagság követelményeit az euróbevezetéstől függetlenül teljesíteni kellene, mert ez egybeesik a gazdasági stabilizáció, valamint a kiegyensúlyozott és fenntartható növekedési pályára való visszatérés követelményeivel" (Palánkai [2012] 722. o.).

Palánkai Tibor nemcsak aktív, termékeny, a nemzetközi akadémiai színtéren is komoly elismerésben részesülő kutató, a hazai integrációs folyamatokat meghatározó módon alakító szakember, hanem iskolateremtő egyéniség, akinek tanórái, gondolatai, írásai számtalan formában és módon inspiráltak sokunkat itthon - és határokon kívül is. Isten éltessen, Tibor!

\footnotetext{
${ }^{2}$ Véleményét egyebek mellett $\mathrm{Az}$ euróövezet német problémájához címủ írásában fejtette ki (Palánkai [2017b]).
} 


\section{Hivatkozások}

Palánkai Tibor [1995/1999]: Az európai integráció gazdaságtana. Aula Kiadó, Budapest.

PalÁnkai Tibor [2012]: Az önálló árfolyam-politika feladása nem okoz igazi veszteséget! Közgazdasági Szemle, 59. évf. 6. sz. 722-726. o.

Palánkai Tibor [2015]: The introduction of the Euro and Central Europe. Economics and Sociology, Vol. 8. No. 2. 51-69. o.

Palánkai Tibor [2017a]: Gondolatok a 21. századi kapitalizmusról és a szociális államról. Thomas Piketty A töke a 21. században címü könyvének inspirációja alapján. Magyar Tudomány, 178. évf. 1. sz. 34-43. o.

Palánkai Tibor [2017b]: „Az euróövezet német problémájához”. 444.hu, október 17. https://444.hu/2017/10/17/palankai-tibor-az-euro-ovezet-nemet-problemaja-hoz.

Palánkai Tibor-Kengyel Ákos-Kutasi Gábor-Benczes István-Nagy Sándor Gyula [2011]: A globális és regionális integráció gazdaságtana. Akadémiai Kiadó, Budapest.

Palánkai Tibor-Miklós Gábor [2014]: Magyarország integrációs profilja. Az európai integráció negyedszázados és a magyar EU-tagság tízéves mérlege. Közgazdasági Szemle, 61. évf. 4. sz. 452-485. o.

TóTh Teréz [2006]: A tudás alapú társadalmak korának dilemmái - kérdések és válaszok. Interjú Palánkai Tibor közgazdász egyetemi tanárral, a Corvinus Egyetem Európai Tanulmányi és Oktatási Központjának igazgatójával. Új Pedagógiai Szemle, 12. sz. http://epa. oszk.hu/00000/00035/00109/2006-12-np-Toth-Tudas.html.

Benczes István

Benczes István a BCE Világgazdasági Intézetének intézetvezető egyetemi tanára (e-mail: istvan. benczes@uni-corvinus.hu). 